\title{
Can the Intermittent Training Generate Alterations on the Liver Tissue of Rats Submitted to a Hyperlipidic Diet?
}

\author{
¿El Entrenamiento Intermitente Puede Generar Alteraciones sobre el \\ Tejido Hepático de Ratas Sometidas a una Dieta Alta en Grasa?
}

\begin{abstract}
Alan José Barbosa Magalhães"; Robson Chacon Castoldi******; Regina Celi Trindade Camargo*; Guilherme Akio Tamura Ozaki*; Regiane Rocha Costalonga*; Rafael Junges Moreira*; Patricia Monteiro Seraphim* \& José Carlos Silva Camargo Filho*
\end{abstract}

MAGAlHÃES, A. J. B.; CASTOLDI, R. C.; CAMARgo, R. C. T.; OZAKI, G. A. T.; COSTALONGA, R. C.; MOREIRA, R. J.; SERAPHIM, P. M. \& CAMARGO FILHO, J. C. S. Can the intermittent training generate alterations on the liver tissue of rats submitted to a hyperlipidic diet? Int. J. Morphol., 34(1):90-96, 2016.

SUMMARY Studies indicate that increasing physical activity and decreasing levels of fat in the liver help to decrease the risk of morbidity from liver conditions. This study aimed to evaluate the effects of an eight week intermittent training program on the liver tissue of rats subjected to a hyperlipidic diet. The study consisted of 30 male Wistar rats, divided into the following groups: Sedentary Control (SC) Exercise Control (EC) (fed on standard feed and water) Sedentary Obese (SO) and Exercise Obese (EO) (fed on bacon, ham, sausage, biscuits, soda and standard feed), which performed intermittent training through electrically stimulated jumps, with three sets of 12 repetitions, three times per week for eight weeks. At the end of the training period, the animals were euthanized, and their livers removed for histological processing and hematoxylin and eosin staining (HE). Soon afterwards, caryometric analysis of the hepatocyte nuclei was performed. From the presented results it can be seen that the hepatocyte nuclei of the obese animals were smaller in relation to those of the control animals, therefore, exercise combined with an appropriate diet proved to be efficient in not causing alterations in the hepatocyte nuclei, conserving normal cell function and reducing the chances of the appearance of tissue damage. Furthermore, exercise in isolation cannot be considered a protective factor against the alteration of the liver cells.

KEY WORDS: High fat diet; Exercise; Hepatocytes.

\section{INTRODUCTION}

Obesity is characterized by a disproportionate consumption of calories in relation to its expenditure for a long period of time, in which the excess of energy is stored as triglycerides in white adipose tissue cells (Speakman, 2013).

Exercise is a stress factor for the liver, due to its central role in maintaining glucose and lipid homeostasis and its function as an energy supplier for muscular work (Fritsche et al., 2008). An increase in physical activity together with a decrease in levels of fat in the liver can help reduce the risk of morbidity from liver disease (Spassiani \& Kuk, 2008).

The pattern of mobilization of energy substrates during exercise can be characterized as a sequence of three phases whose predominant energy substrates are: blood glucose, muscle glycogen and circulating free fatty acids (FFA) (Silveira et al., 2011). In exercises of low to moderate intensity and long duration, an increase in liver and heart glycogen depletion and an increase in FFA oxidation occur (Silveira et al.).

High intensity training diminishes visceral adipose tissue and acts on weight loss by increasing total energy expenditure and excess post-exercise oxygen consumption (EPOC), increasing food-induced thermogenesis and leptin activity and decreasing systolic and diastolic blood pressure whilst inducing the secretion of vasodilator substances such as nitric oxide (Gutierres \& Martins, 2008). Thus, the liver plays an important role in providing energy substrates to working muscles during physical exercise, acting synergistically with the energy reserves of the skeletal muscle. However, no studies were found emphasizing the effects of intermittent exercise and how it correlates to morphological changes in the liver tissue.

\footnotetext{
" Department of Physical Therapy, Paulista State University "Júlio de Mesquita Filho" (Presidente Prudente Campus), Presidente Prudente, Brazil.

** Department of Physical Education, Oeste Paulista University, Presidente Prudente, Brazil.

*** Department of Orthopedy and Traumatology, Campinas State University, Campinas, Brazil.
} 
The hypothesis of this study was that intermittent training would exercise a protective factor on the liver tissue of animals because, as stated above, physical exercise induces energy expenditure thereby preventing the accumulation of lipids in hepatic tissue, thus avoiding an increase in intrahepatic triglycerides and the subsequent formation of inflammatory foci (steatosis). Therefore, the present study aimed to evaluate the effect of an eight week intermittent training program on the liver tissue of rats with a hyperlipidic diet.

\section{MATERIAL AND METHOD}

Animals. Thirty male Wistar rats of 90 days of age were obtained. They were kept collectively in plastic cages $(30 \mathrm{x}$ $16 \times 19 \mathrm{~cm})$. The animals were housed in groups of three to five animals per cage, at an average temperature of $22 \pm 2{ }^{\circ} \mathrm{C}$ and light/dark cycles of $12 \mathrm{~h}$ with the light cycle starting at 07:00 am. The 30 animals were separated randomly into the following groups (Table I):

Table I. Division of animals by experimental group.

\begin{tabular}{lcc}
\hline Group & Initial n & Final n \\
\hline Sedentary Control - SC & 5 & 5 \\
Exercise Control - EC & 10 & 9 \\
Sedentary Obese - SO & 5 & 4 \\
Exercise Obese - EO & 10 & 9 \\
Total & 30 & 27 \\
\hline
\end{tabular}

The animals in the SC and EC groups were fed on standard rodent feed (Supra Lab ${ }^{\circledR}$ brand - Alisul Ind. Alimentos Ltda) with tap water provided ad libitum. The SO and EO groups, from the second month of life, followed a hyperlipidic diet (cafeteria diet), as used by Panveloski-Costa et al. (2011), adapted from Lamas et al. (2004).

Intermittent Training. The model of intermittent strength training "Jump Squat" used in the project was adapted from that proposed by Tamaki et al. (1992). The apparatus was designed so that the animal was immobilized over a metal platform by means of an adapted vest.

Electrical stimulation was performed using a metal clip attached to the end of the tail of the animal and to an electrical stimulator (Dualpex 961, from Quarker ${ }^{\circledR}$ ), calibrated by Inmetro $^{\circledR}$. The parameters used were: frequency $1 \mathrm{Hertz}(\mathrm{Hz})$, duration of $0.3 \mathrm{~s}$ with an interval of $2 \mathrm{~s}$ between each electrical stimulant and the intensity adjusted so that the animal executed the movement, ranging from 3 to 6 milliamperes (mA).
These parameters were adopted as being bidirectional pulses of zero mean, presenting no electrolytic effects and allowing long-term use without risk of tissue damage. At the stimulation, the animals performed full leg extension movements (knee and ankle), lifting a load which had been placed on the back of the vest.

The load was adjusted weekly according to the weekly BW variations (de Lima et al., 2008). This training protocol, proposed by Panveloski-Costa et al., began together with a hyperlipidic diet when the animals reached a young adult age; two months old.

Histological procedures. Twenty-four hours after the last training session, the animals were anesthetized and the euthanasia process was performed.

A paramedian incision was made in the abdomen, and the epithelial tissue folded until the organs were exposed. Shortly after the incision, the liver was removed from the animal, for the extraction of the right upper lobe, the material used for analysis, which was immediately fixed in a $10 \%$ formalin solution.

After 24 hours, the organ was transferred to vials containing $70 \%$ alcohol. This solution was renewed daily for three days, to eliminate any residues of the fixer (Camargo Filho et al., 2011). After fixation and storage in $70 \%$ alcohol, the procedure for inclusion of the material in paraffin was performed and it was subsequently cut in a rotary microtome Microm HM $325^{\circledR}$, with transverse cuts of $6 \mu \mathrm{m}$ thickness. Staining was performed using Hematoxylin and Eosin (HE) according to the methods of Dal Pai Silva (1995).

The caryometric analysis was performed using the methods of Martins et al. (2010), an evaluation was conducted of the hepatocyte nuclei images obtained using an optical microscope Nikon ${ }^{\circledR}$ H550, with a 100x magnification lens, coupled with a Nikon ${ }^{\circledR}$ Infinity 1 digital camera. The images were captured using the NIS-Elements D 3.0 - SP7 - build 547, Nikon ${ }^{\circledR}$ for Windows ${ }^{\circledR}$ software for computerized image analysis. A caryometric analysis was performed using ImagePro Plus 4.5.0.29 for Windows ${ }^{\circledR}$ 98-NT-2000 software for computerized image analysis from Media Cybernetics Inc.

Statistical Analysis. For statistical comparison of the morphometric results obtained from both groups (Control and Obese), the Levene's Test was used to verify the normality of the data, and the ANOVA One-Way Test along with the Turkey's Post-Test (Kruskall-Wallis Test and Dunn's Post-Test for nonparametric data) for comparison of the results. The significance value was set at $(\mathrm{p}<0.05)$ for all procedures. Calculations were performed using the SPSS 17.0 for Windows ${ }^{\circledR}$ application. 


\section{RESULTS}

The initial and final weight of the animals was measured and there was a significant difference comparing the weight gain values between: SC-EC ( $p<0.01)$, SC-SO ( $p<0.02)$ ECSO (p <0.001) EC-EO $(\mathrm{p}<0.005)$ and the SO-EO $(\mathrm{p}<0.05)$.

After analyzing the data, changes obtained by caryometry were observed. The mean values demonstrated that in the comparison made between groups it could be observed that the caryometric variables largest diameter $(\mathrm{p}=$ $0.019)$, smallest diameter $(\mathrm{p}=0.005)$, average diameter $(\mathrm{p}=$ $0.010)$, perimeter $(\mathrm{p}=0.003)$, volume $(\mathrm{p}=0.002)$, area $(\mathrm{p}=$ $0.007)$, and the volume/area ratio $(\mathrm{p}=0.006)$ showed statistically significant differences between the SC and EO groups.

In addition to the smallest diameter ( $\mathrm{p}=0.019)$, volume/ area ratio $(\mathrm{p}=0.044)$ for EC and EO groups (Table II).

Table II. Mean and Standard Deviation of the values of the largest, smallest and average diameter $(\mu \mathrm{m}), \mathrm{D} / \mathrm{d}$, perimeter $(\mu \mathrm{m})$, volume $\left(\mu \mathrm{m}^{3}\right)$, area $\left(\mu \mathrm{m}^{2}\right)$, volume/area, shape coefficient, contour index and eccentricity of the liver tissue of the rats between groups.

\begin{tabular}{|c|c|c|c|c|}
\hline Variables & $\operatorname{SC}(n=5)$ & $\operatorname{EC}(n=9)$ & SO $(n=4)$ & $\operatorname{EO}(n=9)$ \\
\hline $\begin{array}{l}\text { L. Diameter } \\
M \pm S D\end{array}$ & $0.718 \pm 0.065 \mathrm{a}$ & $0.671 \pm 0.051$ & $0.642 \pm 0.041$ & $0.635 \pm 0.026$ \\
\hline $\begin{array}{l}\text { S. Diameter } \\
\text { Med (IR) }\end{array}$ & $0.410(0.04)^{\mathrm{a}}$ & $0.380(0.01)^{\mathrm{a}}$ & $0.360(0.04)$ & $0.330(0.03)$ \\
\hline $\begin{array}{l}\text { A. Diameter } \\
\text { Med (IR) }\end{array}$ & $0.540(0.05)^{\mathrm{a}}$ & $0.520(0.10)$ & $0.485(0.05)$ & $0.460(0.03)$ \\
\hline $\begin{array}{l}\text { Perimeter } \\
\mathrm{M} \pm \mathrm{SD}\end{array}$ & $1.826 \pm 0.135 \mathrm{a}$ & $1.690 \pm 0.155$ & $1.605 \pm 0.094$ & $1.562 \pm 0.063$ \\
\hline $\begin{array}{l}\mathrm{D} / \mathrm{d} \\
\mathrm{M} \pm \mathrm{SD}\end{array}$ & $1.844 \pm 0.268$ & $1.771 \pm 0.273$ & $1.860 \pm 0.072$ & $1.990 \pm 0.111$ \\
\hline $\begin{array}{l}\text { Volume } \\
\mathrm{M} \pm \mathrm{SD}\end{array}$ & $0.092 \pm 0.014 \mathrm{a}$ & $0.076 \pm 0.021 \mathrm{a}$ & $0.067 \pm 0.012$ & $0.055 \pm 0.010$ \\
\hline $\begin{array}{l}\text { Area } \\
\text { Med (IR) }\end{array}$ & $0.240(0.04)^{\mathrm{a}}$ & $0.220(0.07)$ & $0.190(0.04)$ & $0.170(0.02)$ \\
\hline $\begin{array}{l}\text { Volume/Area } \\
\text { Med (IR) }\end{array}$ & $0.360(0.04)^{\mathrm{a}}$ & $0.350(0.07)$ & $0.320(0.03)$ & $0.310(0.02)$ \\
\hline $\begin{array}{l}\text { S. Coefficient } \\
M \pm S D\end{array}$ & $0.872 \pm 0.051$ & $0.888 \pm 0.049$ & $0.872 \pm 0.012$ & $0.847 \pm 0.019$ \\
\hline $\begin{array}{l}\text { Outline Index } \\
\mathrm{M} \pm \mathrm{SD}\end{array}$ & $3.810 \pm 0.119$ & $3.780 \pm 0.125$ & $3.817 \pm 0.029$ & $3.875 \pm 0.052$ \\
\hline $\begin{array}{l}\text { Eccentricity } \\
\mathrm{M} \pm \mathrm{SD}\end{array}$ & $0.806 \pm 0.061$ & $0.788 \pm 0.049$ & $0.810 \pm 0.008$ & $0.831 \pm 0.016$ \\
\hline
\end{tabular}

$\mathrm{M}=$ Mean; $\mathrm{SD}=$ Standard Deviation; Med= Median; IR= Interquartile Range. The ANOVA One-Way (Tukey Post-Hoc) or Kruskall-Wallis (Dunn Post-Hoc) for comparison of the results. The significance value was set at $(\mathrm{p}<0.05)$ for all procedures. ${ }^{a}$ Statistically significant difference compared to group EO.

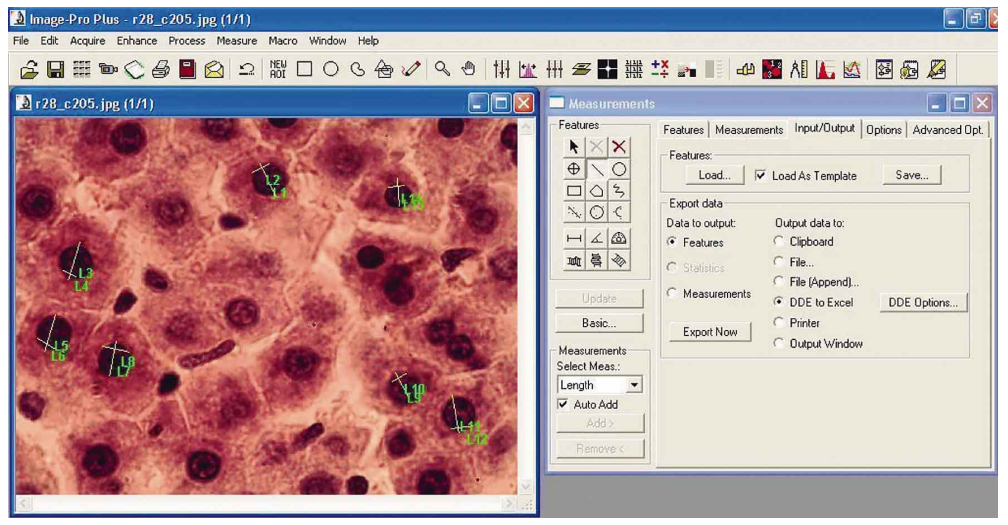

Fig. 1. Usage of the software Image-Pro Plus 4.5.0.29 for Windows 98-NT-2000, from Media Cybernetics Inc. for Windows ${ }^{\circledR}$. 


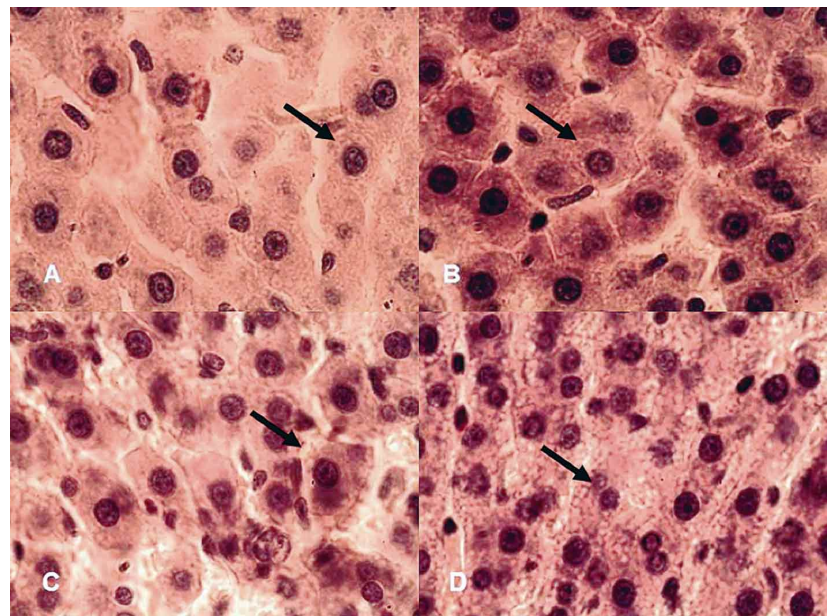

Fig. 2. Photomicrography of the liver tissue of the rats, cut with a thickness of $6 \mu \mathrm{m}$ and stained by H-E. The arrows point to the nuclei of the hepatocytes. Legend: $\mathrm{A}=$ group $\mathrm{SC} ; \mathrm{B}=$ group $\mathrm{EC}$; $\mathrm{C}=\operatorname{group} \mathrm{SO} ; \mathrm{D}=$ group $\mathrm{EO} .100 \mathrm{X}$.
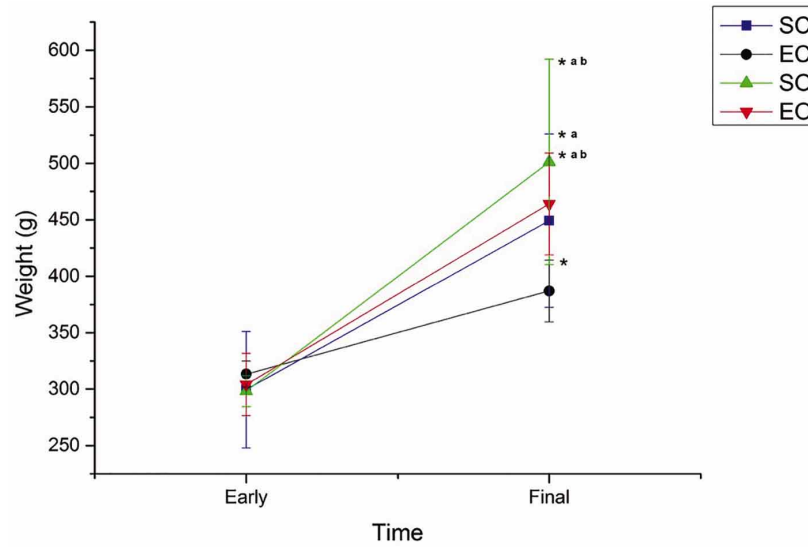

$\sim-\mathrm{EO}$

Fig. 3. Early and final animals weight. $*=p<0,05 ; a=$ at diference $\mathrm{EC} ; \mathrm{b}=$ at diference SC.

\section{DISCUSSION}

The present study aimed to investigate the effects of intermittent exercise on the liver tissue of animals subjected to a hyperlipidic diet.

The body weight of the animals was measured at the start and end of the experiment, in which was found with a statistically significant difference that the body weight of the EC group is less than the ones from the EO and SO groups.

Chapados \& Lavoie (2010) found that visceral fat mass levels of animals that exercised and were submitted to a hyperlipidic diet were lower at the end of the experimental phase in comparison to the visceral fat mass of animals submitted to the same diet who did not perform physical activities.

Eder (2009) corroborates the results of this study, finding that intermittent training showed an increase in depletion of post-exercise VLDL-TAG and decrease in hepatic deposits of TAG, suggesting higher transport of triacylglyceride to the periphery, seeking to replenish the intramuscular deposits in the post exercise.

Garekani et al. (2011) points out that the total fat levels in animals with high and moderate levels of exercise are lower compared to sedentary animals, because such alterations also depend on the adaptations the body realizes in the metabolism to meet the energy expenditure during the practice of the exercise.

In the caryometric analysis, the comparison between groups points out that the caryometric variables largest diameter $(p=0.019)$, smallest diameter $(p=0.005)$, average diameter $(\mathrm{p}=0.010)$, perimeter $(\mathrm{p}=0.003)$, volume $(\mathrm{p}=$ $0.002)$, area $(\mathrm{p}=0.007)$, and the volume/area ratio $(\mathrm{p}=0.006)$ presented statistically significant differences between the groups SC and EO.

Besides the variables of smallest diameter $(p=0.019)$, volume/area ratio $(\mathrm{p}=0.044)$ for $\mathrm{EC}$ and $\mathrm{EO}$ groups, there were no statistically significant differences comparing the $\mathrm{SC}$ group variables with the other groups.

In a study by Menguini et al. (2012) it was observed that obesity in the liver of Wistar rats induced macrovesicular steatosis similar to grade 2, characterized principally by ballooning degeneration. In a study by Syn et al. (2012), significant development in hepatic steatosis and fibrosis was observed in an eight week period, due to the natural death of T cells. Thus, the alterations presented in the liver of the animals belonging to the $\mathrm{SO}$ group could be correlated with the diet (responsible factor).

The variation in the nuclei sizes in the SO group corresponds to the anisonucleosis process, also observed by Guzman et al. (2011) in cases of toxic and metabolic steatohepatitis, autoimmune hepatitis and other liver diseases. Jarrar \& Taib (2011) also observed a slight anisonucleosis in sub toxic doses of lead poisoning in Wistar rats.

The pathogenesis of anisonucleosis in non-neoplastic liver diseases is not well understood, but is probably consistent with the morphological manifestation of nuclear injury from a variety of mechanisms (hepatitis $\mathrm{C}$ virus, metabolic disorders, toxic steatohepatitis, autoimmune hepatitis and other chronic liver diseases in humans) (Guzman et al.). 
Possibly, this phenomenon occurred in the hepatocyte nuclei of the SO group due to the accumulation of lipids (with consequent formation of steatohepatitis). Pórtela et al. (2007), verified in pregnant rats that the administration of aspartame, diluted in distilled water at room temperature, also presented a decrease in the values of the variables related to the size of the hepatocyte nuclei compared to the control group, due to the toxicity of the substance on the liver.

Batista et al. (2006), in a caryometric study, observed the action of an infusion of Cayaponia tayuya on mice and found that the hepatocyte nuclei were higher than the nuclei of animals which had not been treated with the plant. These latter findings indicate that hepatocyte anisonucleosis occurs due to the exposure of the tissue to agents (toxic or not) or high stress situations which provide greater work demands, with consequent cellular apoptosis and tissue injury.

The results also demonstrate the size of the EO group cell nuclei to be smaller in relation to the EC. However, the EO group had a differentiating factor, in addition to diet; intermittent training. The results of Chapados et al. (2009) corroborate the findings of this study, stating that coupled with a reduction in the content of triacylglycerides in the liver, physical training reduces the synthesis of VLDL (Very Low Density Lipoprotein) in fed rats which have had obesity induced by high fat levels, via microsomal triglyceride transfer protein.

A study by Almeida et al. (2008) showed that an increase in the hepatic lipid content occurs proportionally to the original value. The effects of exercise training in this study are possibly associated with the effects of nutritional intake, i.e., the diet of the EO animals may have mitigated the effects of physical training.

Studies in rats indicate that a diet rich in fatty acids can modulate the damage caused in liver tissue, generating dyslipidemia, excessive weight and liver injury with increased steatosis and fibrosis in the liver tissue, due to the production of large quantities of TNF- $\alpha$ (Tumor Necrosis Factor ) generated by the adipose tissue (Neves et al., 2006).

Possibly, the decrease in the nuclear volume showed by caryometric analysis in the animal's tissues of $\mathrm{SO}$ and $\mathrm{EO}$ groups in relation to the animal's tissues of SC and EC groups, reflects the decrease in metabolic activities of these ones. Chapado \& Lavoie, state that the excess lipids mobilized from the adipose tissue during exercise in addition to the lipids from the diet that are mobilized through the liver while inhibiting the synthesis of VLDL and MTP (Microsomal Triglyceride Transfer Protein), can aggravate framework of hepatic steatosis even in physical training situation.
Fabbrini et al. (2010) add to this by stating that high levels of intrahepatic triglycerides can cause metabolic abnormalities independent of BMI, percentage body fat or visceral fat mass. Therefore, from the histological findings, it appears that physical exercise acting in isolation was not a protective factor against the alteration of the liver cells; it needs to be combined with other factors such as a low-calorie diet.

This study was limited to analyzing nucleic changes of liver tissue. However, future studies may collaborate with the literature by quantifying the number of cells, in which it can be pointed out in what proportion the liver needs to adapt its number of hepatocytes, from a normal condition to an exercised condition or a condition of obesity, as well as possible changes in extracellular matrix in the liver tissue, for example, quantifying the concentration of fatty acids.

It can be concluded therefore, that the exercise combined with proper diet was efficient in not causing significant changes in the nuclei of hepatocytes, being able to retain its normal functions and reducing the chances of the appearance of lesions in the tissue. In addition to that, the exercise alone cannot be considered a protection factor of liver cells.

\section{ACKNOWLEDGEMENTS}

This study was funded by the National Council for Scientific and Technological Development (CNPq).

MAGALHÃES, A. J. B.; CASTOLDI, R. C.; CAMARGO, R. C. T.; OZAKI, G. A. T.; COSTALONGA, R. C.; MOREIRA, R. J.; SERAPHIM, P. M. \& CAMARGO FILHO, J. C. S. ¿El entrenamiento intermitente puede generar alteraciones sobre el tejido hepático de ratas sometidas a una dieta alta en grasa? Int. $J$. Morphol., 34(1):90-96, 2016.

RESUMEN: Estudios indican que el aumento de la actividad física y la disminución de los niveles de grasa en el hígado ayudan a reducir el riesgo de morbilidad por enfermedades hepáticas. El objetivo fue evaluar el efecto de un programa de entrenamiento intermitente de ocho semanas en el tejido hepático de ratas con dieta alta en grasa. Treinta ratas Wistar machos fueron divididas en grupos Control Sedentario (SC), Control Ejercicio (CE) (con fuente de alimentación que consiste en la ración estándar y agua), Obeso Sedentario (OS) y Obeso Ejercicio (OE) (con alimentación compuesta por tocino, mortadela, salchichas, galletas, refrescos y ración estándar), sometidas a un entrenamiento intermitente a través de saltos mediante estimulación eléctrica con tres series de 12 repeticiones, tres veces por semana durante ocho semanas. Al final del período de entrenamiento, los animales fueron sacrificados; se 
extrajeron sus hígados para el procesamiento histológico y tinción con hematoxilina y eosina (HE). Luego se realizó el análisis cariométrico de los núcleos de los hepatocitos. Se observó que los núcleos de los hepatocitos fueron menores en los animales obesos en comparación con los núcleos de hepatocitos de los animales de control, pues el ejercicio combinado con una dieta adecuada se mostró eficiente para que causar alteraciones en los núcleos de hepatocitos, y esa combinación puede retener la función normal de las células y disminuir las posibilidades de la aparición de daños en los tejidos. Además, el ejercicio aislado no puede ser considerado como un factor de protección contra la alteración las células del hígado.

PALABRAS CLAVE: Dieta alta en grasa; Ejercicio; Hepatocitos.

\section{REFERENCES}

Almeida, F. N.; Almeida, K. N.; Mais, L. N.; Nachbar, R. T.; Natali, M. R. M. \& Moraes, S. M. F. A resposta do peso e da composição corporal à inclusão da dieta de cafeteria e treinamento físico aeróbio em diferentes fases do desenvolvimento. Cienc. Cuid. Saude, 7(Suppl. 1):39-44, 2008.

Batista, A. G. U.; Lopes, R. A.; de Souza, M. A.; Kasai, A.; Lopes, P. E. V. P.; Sala, M. A.; Regalo, S. C. H. \& Petenusci, S. O. Hepatotoxicidade de plantas medicinais. XLIX. Ação da infusão de Cayaponia tayuya (Vell.) Cogn. no camundongo. Investigação - Rev. Cienc. Univ. Franca, 6(1):7-11, 2006.

Camargo Filho, J. C. S.; Garcia, B. C.; Kodama, F. Y.; Bonfim, M. R.; Vanderlei, L. C. M.; Ramos, E. M. C.; Camargo, R. C. T.; Padulla, S. A. T. \& Maeda, J. K. Effects of aerobic exercise on the skeletal muscle of rats exposed to cigarette smoke. Rev. Bras. Med. Esporte, 17(6):412-415, 2011.

Chapados, N. A.; Seelaender, M.; Levy, E. \& Lavoie, J. M. Effects of exercise training on hepatic microsomal triglyceride transfer protein content in rats. Horm. Metab. Res., 41(4):28793, 2009.

Chapados, N. A. \& Lavoie, J. M. Exercise training increases hepatic endoplasmic reticulum (er) stress protein expression in MTP-inhibited high-fat fed rats. Cell. Biochem. Funct., 28(3):202-10, 2010.

Dal Pai Silva, M. Histoenzimologia: Teoria e Prática. Botucatu, Instituto de Biociências - UNESP, 1995.

de Lima, C. D.; Alves, L. E.; Iagher, F.; Machado, A. F.; Bonatto, S. J.; Kuczera, D.; de Souza, C. F.; Pequito, D. C.; Muritiba, A. L.; Nunes, E. A. \& Fernandes, L. C. Anaerobic exercise reduces tumor growth, cancer cachexia and increases macrophage and lymphocyte response in Walker 256 tumorbearing rats. Eur. J. Appl. Physiol., 104(6):957-64, 2008.
Eder, R. O Exercício Intermitente Modula o Metabolismo Lipídico em Ratos: O Fígado como Órgão Gerenciador. PhD Thesis. São Paulo, Universidade de São Paulo, 2009.

Fabbrini, E.; Sullivan, S. \& Klein, S. Obesity and nonalcoholic fatty liver disease: biochemical, metabolic, and clinical implications. Hepatology, 51(2):679-89, 2010.

Fritsche, L.; Weigert, C.; Häring, H. U. \& Lehmann, R. How insulin receptor substrate proteins regulate the metabolic capacity of the liver--implications for health and disease. Curr. Med. Chem., 15(13):1316-29, 2008.

Garekani, E. T.; Mohebbi, H.; Kraemer, R. R. \& Fathi, R. Exercise training intensity/volume affects plasma and tissue adiponectin concentrations in the male rat. Peptides, 32(5):1008-12, 2011.

Gutierres, A. P. M. \& Marins, J. C. B. Os efeitos do treinamento de força sobre os fatores de risco da síndrome metabólic. Rev Bras. Epidemiol., 11(1):147-58, 2008.

Guzman, G.; Chennuri, R.; Voros, A.; Boumendjel, R.; Locante, A.; Patel, R. \& Valyi-Nagy, T. Nucleometric study of anisonucleosis, diabetes and oxidative damage in liver biopsies of orthotopic liver transplant recipients with chronic hepatitis C virus infection. Pathol. Oncol. Res., 17(2):191-9, 2011.

Jarrar, B. M. \& Taib, N. T. Histological and histochemical alterations in the liver induced by lead chronic toxicity. Saudi J. Biol. Sci., 19(2):203-10, 2012.

Lamas, O.; Martínez, J.A. \& Marti, A. Energy restriction restores the impaired immune response in overweight rats. J. Nutr. Biochem., 15(7):418-25, 2004.

Martins, A. T.; Santos, F. S.; Scannavino, L. F.; Pires, J. R.; Zuza, E. P.; Junior, J. A. P.; Azoubel, R.; Di Mateo, M. A. S. \& Lopes, R. A. Effect of sodium cyclamate on the rat fetal exocrine pancreas: a karyometric and stereological study. Int. J. Morphol., 28(3):899-904, 2010.

Menguini, R.; Casagrande, V.; Menini, S.; Marino, A.; Marzano, V.; Hribal, M. L.; Gentileschi, P.; Lauro, D.; Schillaci, O.; Pugliese, G.; Sbraccia, P.; Urbani, A.; Lauro, R. \& Federici, M. TIMP3 overexpression in macrophages protects from insulin resistance, adipose inflammation, and nonalcoholic fatty liver disease in mice. Diabetes, 61(2):454-62, 2012.

Neves, R. H.; Alencar, A. C.; Aguila, M. B.; Mandarim-de-Lacerda, C. A.; Machado-Silva, J. R. \& Gomes, D. C. Hepatic stereology of Schistosomiasis mansoni infected-mice fed a high-fat diet. Mem. Inst. Oswaldo Cruz, 101 (Suppl. 1):253-60, 2006.

Panveloski-Costa, A. C.; Pinto Júnior, D. A.; Brandão, B. B.; Moreira, R. J.; Machado, U. F. \& Seraphim, P. M. Resistive training reduces inflammation in skeletal muscle and improves the peripheral insulin sensitivity in obese rats induced by hyperlipidic diet. Arq. Bras. Endocrinol. Metabol., 55(2):15563, 2011. 
MAgAlHães, A. J. B.; CASTOLDI, R. C.; CAMARgo, R. C. T.; OZAKI, G. A. T.; COSTAlONGA, R. C.; MOREIRA, R. J.; SERAPHIM, P. M. \& CAMARGO FILHO, J. C. S. Can the intermittent training generate alterations on the liver tissue of rats submitted to a hyperlipidic diet? Int. J. Morphol., 34(1):90-96, 2016.

Pórtela, G. S.; Azoubel, R. \& Batigália, F. Effects of aspartame on maternal-fetal and placental weights, length of umbilical cord and fetal liver: A kariometric experimental study. Int. J. Morphol., 25(3):549-54, 2007.

Silveira, L. R.; Pinheiro, C. H.; Zoppi, C. C.; Hirabara, S. M.; Vitzel, K. F.; Bassit, R. A.; Barbosa, M. R.; Sampaio, I. H.; Melo, I. H.; Fiamoncini, J.; Carneiro, E. M. \& Curi, R. Regulation of glucose and fatty acid metabolism in skeletal muscle during contraction. Arq. Bras. Endocrinol. Metabol., 55(5):303-13, 2011.

Spassiani, N. A. \& Kuk, J. L. Exercise and the fatty liver. Appl. Physiol. Nutr. Metab., 33(4):802-7, 2008.

Speakman, J. R. Evolutionary perspectives on the obesity epidemic: adaptive, maladaptive, and neutral viewpoints. Annu. Rev. Nutr., 33:289-317, 2013.

Syn, W. K.; Agboola, K. M.; Swiderska, M.; Michelotti, G. A.; Liaskou, E.; Pang, H.; Xie, G.; Philips, G.; Chan, I. S.; Karaca, G. F.; Pereira, Tde. A.; Chen, Y.; Mi, Z.; Kuo, P. C.; Choi, S. S.; Guy, C. D.; Abdelmalek, M. F. \& Diehl, A. M. NKTassociated hedgehog and osteopontin drive fibrogenesis in nonalcoholic fatty liver disease. Gut, 61(9):1323-9, 2012.

Tamaki, T.; Uchiyama, S. \& Nakano, S. A weight-lifting exercise model for inducing hypertrophy in the hindlimb muscles of rats. Med. Sci. Sports Exerc., 24(8):881-6, 1992.

\section{Correspondence to:}

Alan José Barbosa Magalhães

Rua Roberto Simonsen, 305

Centro Educacional, CEP: 19060-900

Presidente Prudente - SP.

BRAZIL

Email: ajb_magalhaes@yahoo.com.br

Received: 15-05-2015

Accepted: 23-12-2015 